\title{
Lost in the Information Age
}

\section{Nicole Brimmer}

\section{Lost In Cyberspace}

One afternoon.

I decided to conduct an experiment into abstraction, chance and writing. This meant interrogating my bookshelves. I started reading through many texts. Reading from top to bottom in an order based on common fate, chance and randomness. I opened up each book, and each text, one at a tim from right to left, and shuffled through the stacks of information. I recorded the information in fragments, grazing on bits and pieces of text, as how : sheep grazes on grass in a paddock. I did this in order to invite chance to intervene in the invention of the language of the artist. I recorded random sections of books, opened up on any particular page, and began this essay.

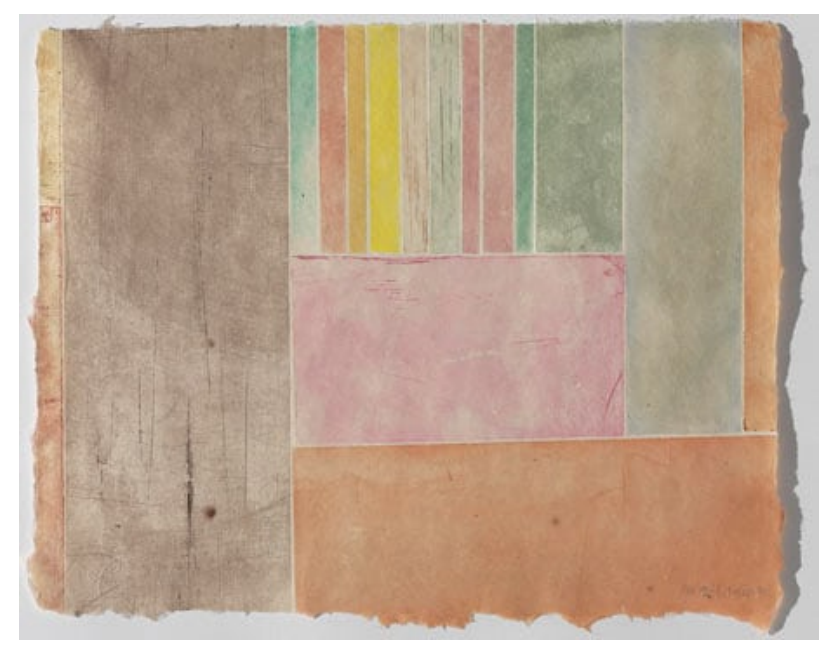

Artwork by John Cage titled HV2

When asked how he constructed his works, whether verbal, visual, or musical, Cage regularly referred to 'chance operations.' The phrase, a staple of Cagean criticism, strikes me as passing strange. Chance, according to The American Heritage Dictionary, is the "abstract nature or quality shared by unexpected, random, or unpredictable events," as well as such events themselves. It is also a "probability," "an opportunity, a risk or hazard; a gamble."[1]

I Approaching my bookshelves, selecting from non-fiction books with titles along the lines of...The Fabric Of The Heavens, The Secret Of The Lion, Design As Art, and Return To The Stars, I opened the first book up on a random page, I pointed to a sentence, I then recorded each sentence to create a montage purely by chance, coincidence and common fate. This montage is pasted into the latter half of this essay.

We know that a text is not a line of words releasing a single 'theological' meaning (the 'message' of the Author God) but a multi-dimensional space in which a variety of writings, none of them original, blend and clash. The text is a tissue of quotations drawn from the unnumerable centers of culture.[2]

As the text and advertisements in the outer world blend and clash, creating an environment filled with chance operation, from viewing posters on bu shelters to billboards, from magazine headlines in shops, to newspapers blowing in the wind on the street, one's every day journey to work and bacl home, is filled with a montage of unexpected information overload. Signs and words, advertisement and collage, all haphazardly placed in an unplanned way, all, create an unintentional dialogue with each other and the viewer. These new messages and meanings play out a role in time and space of the fourth dimension, where the context of the environment and the interplay of the viewer re-contextualize the original intention of the stor

As the audience go about their day, information is relayed to them through a time continuum of chance operation, where their own individual story is played out. This begins from the moment they wake in the morning to the time they retire in the evening, as time and space intersect with informatio broadcast on the airwaves, throughout the day, and well into the evening.

By fusing memoir and essay, chance operations and principles of common fate, I have tried to replicate a feeling of abstraction. Slowly unfolding a narrative from beginning, middle to end, similar to the unravelling of a ball of yarn. In order to reveal a timeline reflecting the slow progression of an audience moving forwards into the overload of the information age, an age filled with chance encounters starting in the inner home filled with outer 
information from books on shelves to watching television and interacting with the internet, to the outer journey of interaction with unintentional corporate montages on the city street.

A montage of text reflects this moment in time. It reflects the moment when one can hear others' thoughts, in fragments, the same sounds as if on were to open a book on any page and read one sentence, put the book down, and then open another on any page, read another sentence and so forth, continuing this process. This is the internal world of the psyche in an external public world of rational thinking in fragments before it is releaser from the mind.

Logic and intuition combined.

The intention of this essay, is to create a mirror reflection, a snapshot of a subjective reality of what life has become, living in the $21^{\text {st }}$ century digital age. So, let's rewind back to the beginning and restart the essay here instead.

Lost in the information age, an age, where one is likened to a mere fly, hopping from one surface to another, collecting and gathering fragments of information and compiling them together into what they might call "Common knowledge" or "common fate."

As a fly spreads disease and germs everywhere it goes, so does the word of mouth of incessant blogging, texting, sharing, citing, recording, uploading, downloading, reading, watching, listening and absorbing loads-and-loads of unnecessary texts. One becomes a navigator or a scaveng $\epsilon$ by jumping from one information scenario to the next, spreading more fragments of irrelevant dialogue, plot and story-telling, injecting this translatio of space and time into today's sophisticated and highly advanced "intelligent" society. A society which seems to pride itself on being capable of communicating and spreading large amounts of excessive information collected everywhere a satellite can project its robotic wings to navigate through space.

Like the fly that zips around spreading its own collective of shit everywhere it goes, breeding maggots and attacking picnics, salads, food dishes an biting legs at the beach, so does information. It fills books everywhere it goes. It blends into backgrounds, it appears on television screens, computers, it enters the world of film, it inhabits people's brains, it gets relayed and regurgitated, recited, retold and reorganised. The newspaper stories get published, the magazines, the columns with the most-latest of news events.

The street press becomes the media's voice, as the art of literature becomes thwarted by mainstream business giants. They are always talking. It never stops. Information is always talking. Information is like a fly who doesn't seem to ever "fly away." One may try to use insect-sprays or electrifiє tennis-rackets to try to protect themselves from the never-ending buzzing of the information age filled with so much noise that one struggles to hear one's own self anymore against the background of sound and visual language infiltration.



Artwork by philosopher Gilles Deleuze titled: Chambre demalade 
A book has neither object nor subject; it is made of variously formed matters, and very different dates and speeds. To attribute the book to a subject is to overlook this working of matters, and the exteriority of their relations. It is to fabricate a beneficent God to explain geological movements In a book, as in all things, there are lines of articulation or segmentarity, strata and territories; but also lines of flight, movements of destratification. Comparative rates of flow on these lines produce phenomena of relative slowness and viscosity, or, on the contrary, of acceleration and rupture. All this, lines and measurable speeds, constitutes an assemblage. ${ }^{[3]}$

To paint a picture, I may start my day in a small city apartment. It begins with my black fluffy Himalayan cat with two white spots on her nose, and fluffy white paws, banging on the door. This happens every morning at approximately $4 \mathrm{am}$. I am asleep in the midst of dreaming. As she taps her black paw with white socks on the venetian blind strung upon the glass door, it wakes me up with a loud repetitive banging noise. She is perhaps th painter, painting the right corner of the door with her black paw. She is commanding her work of art, she is communicating in an audio-visual way, $\mathrm{h}$ message of vocalization becomes louder with the intervention of a string of rods which projects sound much more loudly than she can meow. She is aided to do this by the higher beings who enable her disadvantaged cat like existence to utilize the venetian blinds (an object created for human's only) the same way a sound engineer may utilize an amplifier to create what must be created, a really loud noise that would wake me out of my dreaming state.

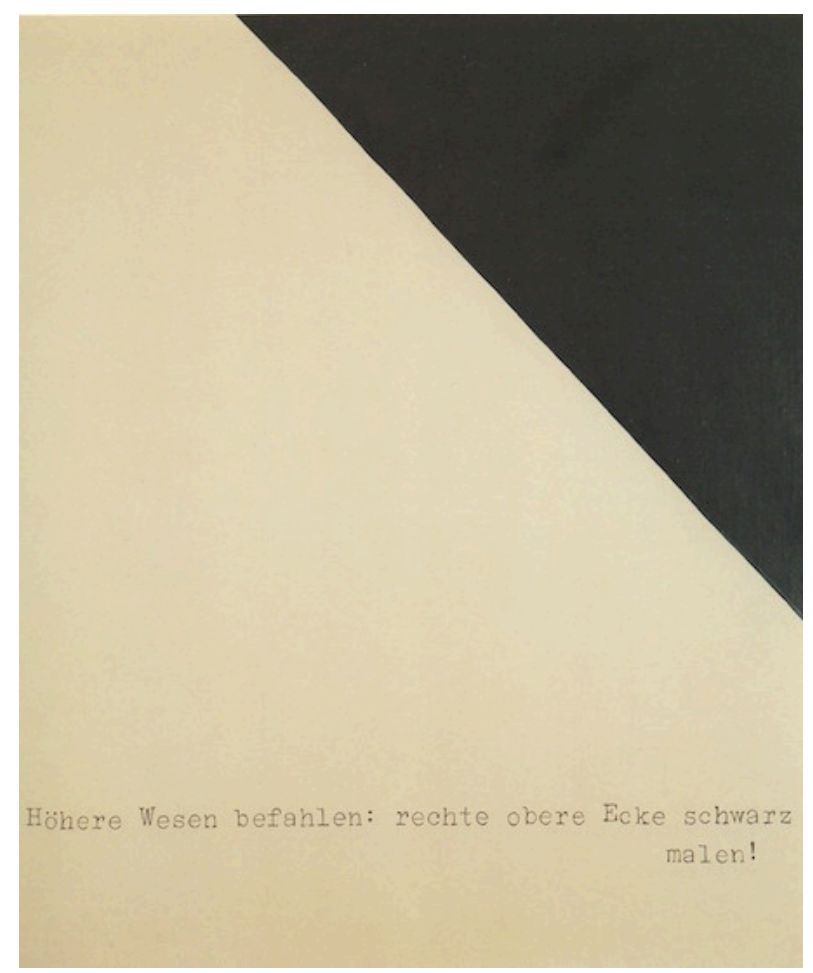

Artwork by Sigmar Polke, titled in English Higher beings commanded : paint the upper right corner black!

The artist here presents himself as a medium, a conduit through which images take root and form. The pictorial pendant to this passage may be recognized as the now famed Hohere Wesen Befahlen! (Higher beings commanded: Paint the upper Right Corner Black!, 1969), a seminal work in Polkes mythology of self. Having spent the decade ostensibly responding to American Pop Art, producing sardonic spoofs of affluent society, Hohere wesen describes both the role of the artist and the mission of painting. The superficial content of the message is clear: the artist, conversant with the language of higher beings, has responded by painting the right corner black. ${ }^{4]}$

Like Sigmar Polke, my cat too communicates with her art, finding her expression and place within the world, her mastery of sound outside of her on cat like capacity, her visual language created all for the need to be outside in nature in the quietest time of day. This time just happens to be in the dead of night, whilst the city sleeps, the moment in time right before the birds start singing and you can actually hear them sing. For there is hardly $a$ background noise. I open the door and I let her out. Into the world. I ponder what the world is like from the point of view of a cat who forever has to use a universal language outside of her own meows to communicate her needs to her rather airy-fairy-telepathic cat owner.

The world is simply the universal 'convenience' of things. ; there are the same number of fishes in the water as there are animals, or objects produced by nature or man, on the land the same number of beings in water and on the surface of the earth as there are in the sky, the inhabitants of the former corresponding with those of the latter; and lastly, there are the same number of beings in the whole of creation as many be found eminently contained in God himself, 'The sower of Existence, of Power, of Knowledge and of Love.' 
Thus, by this linking of resemblance and with space, the 'convenience' that brings like things together and makes adjacent things similar, the world is linked together like a chain.

At each point of contact there begins and ends a link that resembles the one before it and the one after it; and from circle to circle, these similtudes continue, holding the extremes apart (god and matter), yet bringing them together in such a way that the will of the almighty may penetrate into the most unawakened corners.

It is this immense, taut, and vibrating chain, this 'rope of convenience', that Porta evokes in a passage from his Magie naturelle:

As with respect to its vegetation the plant stands convenient to the brute beast, so through feeling does the brutish animal to man, who is conformable to the rest of the stars by his intelligence; these links proceed so strictly that they appear as a rope stretched from the first cause as far as the lowest and smallest of things, by a reciprocal and continuous connection; in such wise that the superior virtue, spreading its beams, reaches so far that if we touch one extremity of that cord it will make tremble and remove all the rest. ${ }^{[5]}$

I lie in bed, all the heat escapes out of my tiny apartment and, of course, I cannot get back to sleep. Nor can I return to the dream. I just continue wi the start of my day. Time moves forwards in real-time signatures only. I lie in bed just listening. The air conditioners of the neighbours' units start buzzing, a mechanical interference with the unusual quietness of the city. The silence of nature is louder than it has ever been, having been slaughtered and replaced with an abundance of unnecessary concrete which seems to make no sound. This rolls into the next sounds of the mornir The birds start singing. Around $5 \mathrm{am}$ in the morning their singing is significantly peaceful, melodic and reassuring that nature does still exist outside human intervention. These shifts of sounds, of time spent in meditation, just listening to the earth talking, move me slowly into my morning routine $\mathrm{c}$ getting ready to enter the so called "outside world," to step out of the quaintness of my tiny home into the quaintness of the rather kitsch journey to work.

The quaintness of a butter churn or a wringer washing machine often derives, not from its ingeniousness, but from how much time it wasted, from its inefficiency, and from the touchingly absurd indefatigability of its users, those indentured kitchen slaves who thrashed rugs permeated with the soot of fossil fuels and milked the family cow at the crack of dawn. In an era of self-defrosting freezers, microwave espresso machines, In-sink-erators, and self cleaning cat litter boxes with laser-beam eyes, labour itself has become quaint and the conspicuous consumption of time has been aestheticized, transformed into a prurient spectacle for a generation that, accustomed to the luxuries of mechanization, re-enacts the past as a form of recreation, performing such activities as crocheting afghans, making candles, and baking cakes from scratch.[6]

I walk down the street to the tram. Chance begins to intervene outside of my control. I walk past houses, in my suburban street, past an occasional passer-by, past random junk on the sidewalk, thrown out debris of junk that has passed its use-by date. I keep walking. Past a giant Billboard whicr advertises five giant sized heads of "The Breakfast Show." Tune in to the breakfast show, it says. Overlaying this text and covering the hideous face: of humanity's last attempt to make themselves known universally is a layer of graffiti, obscuring the original content and paving way for a new meaning. A culture jamming of interaction with the surrounding environment owned by corporate giants who pay for such space to interrogate unsuspecting passers-by on the way to their trains and trams.

"In my December 1990 New York Times article on the subject- the first appearance of the phrase and the concept in the mainstream media-I used Negativland, the media hoaxer, Joey Skaggs, the graffiti artist Robbie Conal, the parody billboard painter Jerry Johnson, And Reverand Ivan Stang of the tongue-in-cheek Church of Subgenius cult as poster for children for culture jamming-media age provocateurs who expose 'the ways in which corporate and political interests use the media as a tool of behaviour modification. ${ }^{[7]}$

I walk to the tram-stop. In this tram-stop happens to exist one of those community book boxes. More information. Sometimes I open this box and look inside at the books the community seems to place inside it. It is often books that are of no relevance to me. With words like this

\section{At work}

One in three workers spent at least three-quarters of their time at work sitting. Managers, professionals and clerical/administrative workers spent an average of 22 to 23 hours per week sitting compared to less than four hours for labourers. Working adults also averaged six hours per week sitting for transport. [8]

I board the tram. In peak hour times. This often means standing, being slammed against the glass, squashed like sardines, by an overcrowded grou of city dwellers. Who, unlike myself, happen to love being switched into their electronic communication devices. Around 20 mobile phones are floati in mid-air, in people's hands as they are hunched over enthralled by the tiny machines, sticking them in my face without even realising. I look arounc the space, trying hard to breathe. Looking up to a place to rest my eyes and I am bombarded by advertising. I look out the window and see lines of trees, roads, houses. humanity in fragments here and there, more billboards, shop fronts, messages on the streets, and an overload of information beginning to ruin my morning, shifting me away from the serene sounds of the birds chirping with the rise of the sun, to the sounds of humanity desperate for an R\&R escape they cannot seem to easily obtain. 
During the past decades, the culture industries have multiplied media spectacles in novel spaces and sites, and spectacle itself is becoming one of the organizing principles of the economy, polity, society, and everyday life. The internet based economy deploys spectacle as a means of promotion, reproduction, and the circulation and selling of commodities. Media culture itself proliferates ever more technologically sophisticated spectacles to seize audiences and increase their power and profit. The forms of entertainment permeate news and information, and a tabloidized infotainment culture is increasingly popular. New multi media that synthesize forms of radio, film, TV news and entertainment, and the mushrooming domain of cyberspace, become spectacles of technoculture, generating expanding sites of information and entertainment, while intensifying the spectacle-form of media culture. ${ }^{[9]}$

I can hear the thoughts of the corporate workers in suits. My psychic-telepathy once again seems like a dangerous disease, an unwanted commodi I wish I lived in the countryside. The thoughts of coffee-fuelled workers fill up the space. I try to tune out; however, their thoughts rattle on louder the they know that my ears are attuned to the higher senses of ESP. I hear fragments of people's thoughts in abstract message systems, a churning tex of other people's stories. All crammed into one small space of the public transport system. This to me is similar-to-hell. Having psychic abilities in a tram-car packed full of unevolved beasts who have no idea your capacity to "hear their thoughts." A montage of text reflects this moment in time.

On all counts the Greek astronomers were prepared to allow that the sphere of the fixed stars was very large. ${ }^{[10]}$ 'Oh thou daughter dwelling in Egypt, furnish thyself to go into captivity : for Noph shall be waste and desolate without an inhabitant.'[11] We know the effects of the absence of gravity, a thing that was inconceivable not so long ago ; a man floating in space, alone, without wings or mechanism of any kind! This we have all seen. ${ }^{[12]}$ The last vibration of the seventh eternity thrills through infinitude. ${ }^{[13]}$

Give your suggestions in the form of words that evoke images, either memories, detailed plans or fantasy symbols. ${ }^{[14]}$ To get to Olivenca take one of the frequent Olivenca buses from the city bus station in Ilheus. ${ }^{[15]}$ Thus the entire episode is a gay carnivalesque travesty of the city's name. ${ }^{[16]}$ Into the Desert Navaho. $1904 .{ }^{[17]}$ Is there an elevator or Laundry Service? ${ }^{[18]}$ See dancing. ${ }^{[19]}$ At the end of the visit, we shook hands warmly. ${ }^{[20]}$

If I ever became friends with a dolphin I would never presume to teach such a creature more evolved than most humans will ever be on the contrary, I would try to learn all the levels of insights and depths of wisdom a dolphin might be kind enough to share with me. ${ }^{[21]}$

Pineapple Fructose 2.1 Glucose 2.9. ${ }^{[22]}$ The skill of doing this movement without turning the game into a wrestling match is in positioning yourself perfectly to take your partner by surprise. ${ }^{[23]}$ He makes his home in the characters and minds of gods and humans; and not in all minds, one after another and whenever he finds one with a soft character he settles down. ${ }^{[24]}$ Now, one November evening shortly after my mother's death, I was going through some photographs. ${ }^{[25]}$

Time is valuable and ten seconds worth of it is well worth the investment of a day's happy activity working out a way of saving it. ${ }^{[26]}$ Werner Herzog was born in Munich on September 5, 1942. ${ }^{[27]}$ September 8 Walking for thousands of Miles, Had you been In Capetown on September $8^{\text {th }}$, 1928, You would of seen a large crowd of people gathered together in the drizzling rain. ${ }^{[28]}$ To send an email/fax. ${ }^{[29]}$

Time goes by. I exit the tram to the city centre. Here I am intersected by wayward pedestrians that aren't looking where they're going, that have no concept of order and are moving in an invisible network of chaos and lack of spacial understanding. Each is focused on themselves and not their surroundings. I look to the street to avoid the insanity of the grim-expressions of overworked, underpaid, over-wanting, not-getting-enough, and needing-more-messages in the eyes of a humanity, born into a system of tyranny, capitalism, egotism, self-indulgence, destruction and chaos. The street surrounding them is filled with logos of corporate giants, taking control of the world. 


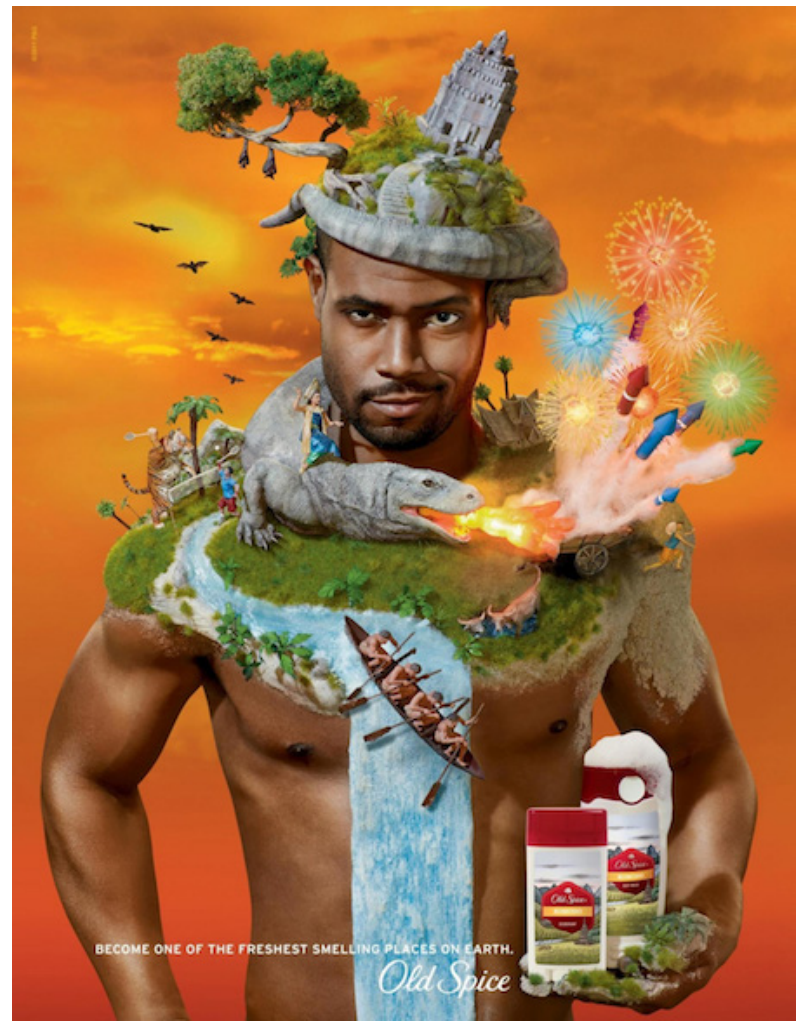

Big Idea / Old Spice 'The Man Your Man Could Smell Like' Ad campaign (Eric Kallman \& Craig Allen of $\mathrm{W}+\mathrm{K}$ )

The backlash against the big idea came from the baggage attached to advertising's idea of a big idea. A big idea is often too attached to the notion of a big, overblown advertising idea-a big, overarching message that must say everything to everyone about a brand, that takes a long time and a lot of money to create and is broadcast out to a specified audience for a finite period of time.

Of consumeristic everythings and anythings all at once from coffee, to patisseries, to aromatic scents of bakeries and delicacies. Shops housing fashionable accessories, vintage paraphernalia, through to corporate propaganda, buy this, get this, you need this. Want this, signs are everywhere. All leaving their information imprints on the vulnerable self-lost in the city street of commodity which disguises itself in the quaintness of illusion.

Quaintness alludes to a time before consumerism when products were not actively marketed to the public but sold themselves on the basis of their reputation for sturdy reliability and not on the basis of their flashy labels and wacky television ads featuring can-can lines of happy cats meowing to snappy jingles and breakfast cereals so fresh that they leap out of their bowls and serenade us like barbershop quartets. Aesthetics such as quaintness rectify problems that consumerism itself creates and event pretend to loathe its flimsy, mass-produced goods which, if they are to be sold to markets wary of being gouged by both high prices and false promises, must be disguised as-one-of-a-kind art objects handcrafted by nimble-fingered grannies in gingerbread cottages, far away from the ominous spectre of dark, satanic mills. [30]

The colours of the traffic-lights switch to flashing signs which switch to unusual sounds, from the mechanical defacing of rhythm in the click of the trams movement on tracks to the awkward voice-overs of safety messages on loud speakers lost in distortion of noise. To remembering to stand behind the yellow line. To exiting the train at the right platform. To clanging, ringing, people coughing, and wheezing. To the sounds of nature dead it the street. And replaced by the sounds of a population of human with parasites growing out of control. They zip like flies from one moment to the $n \epsilon$ Buzzing with phone rings, random chatter, mindless gossip, backstabbing, talking on cell phones. Complaining and scowling down their noses at others. This is the city. The city moves with the motions of kitsch disguised in quaintness. Their thoughts ring louder than their faces show, trapped a one dimensional spiritual existence, inhabitants that have lost their minds to the invisibility of the unseen kitsch of "city-dwellers" dwelling in "citydwellers."

Kitsch's enormous profits are a source of temptation to the avant-garde itself, and its members have not always resisted this temptation. Ambitious writers and artists will modify their work under the pressure of kitsch, If they do not succumb to it entirely. 
Kitsch has not been confined to the cities in which it was born, but has flowed out over the countryside, wiping out folk culture. Nor has it shown any regard for geographical and national cultural boundaries. Another mass product of Western Industrialism, it has gone on a triumphal tour of the world, crowding out and defacing native cultures in one colonial country after another, so that it is now by way of becoming a universal culture, the first universal culture ever beheld. ${ }^{[31]}$

Music plays, from flutes to pop music, to atmospheric sound, to infiltration of media from all sources through touch screens, moving signs, shopfror displays, windows, cars, birds with missing legs, homeless people sleeping on the steps of business tycoons. Corporate giants plastering their messages everywhere they go.

Quaintness is also an aesthetic of clutter because it presents different periods simultaneously. Its chaotic style, reminiscent of many chain restaurants, which cram their dining rooms with old pickle barrels, buggy wheels, and antique German salt pigs, is the outcome of its historical fallaciousness, its scrambled sense of chronology, which mixes together disparate epochs and cultures, collapsing the time line like an accordion. ${ }^{[32]}$

Inner worlds interact with the outer worlds. Two modalities existing in parallels. Disparate thinking, and city-thinking combined. To a certain extent a man loses himself through connecting with his partner. ${ }^{[33]}$ Positive and negative space collide, as in a painting. Once you have power, It's difficult to go. ${ }^{[34]}$ Or in music the sound and the silence. With words can be recorded, the breathing of life, the thoughts that I record, the words that I hear witr my ears. Beauty enlivens the commonplace. ${ }^{[35]}$ The voice that I write with, becomes the language of writing itself. Other people's thoughts invade $\mathrm{m}$ mind like a botox injection to the face.

City people have become "products" of the city they live in. Designs of their cities dictate their ideas in fashion, newspapers, televisions, books, technology and media. The city has shaped their identities, made them who they are. Given them a name like "NIKE," "Just Do It," a job to do such to "Get Seen in Calvin Kleins," an address called "My House in the middle of the street," a "Smart phone" and a "Sleepmaker" mattress to rest with "apple-mac-lap-top-computer" on the side. Marketing and media have given the human their persona, "A mars a day helps you work, rest, and play Given them a market, "Got Milk?" A "smart-phone" to record their lives with and a marketing device to enhance their market. Media is a mere reflection of itself in the creation of humanity. It is the ruler, the human being is the follower. Media has encroached itself from the outskirts of city streets to the inner skirts of everybody's homes.

Product design has come to resemble a form of plastic surgery, something like a Botox injection to the forehead, suppressing frown lines to create a brief illusion of beauty. It's only SIM cards embedded in our phones that have the ability to learn from us, to mark our friendships and our routines through the numbers that we record on them and to make meaningful patterns out of them. But these, like our Google records, can be the source of well justified paranoia as much as of a comfort. [36]

My inner world interacts with the outer world. It is typical for women to be afraid to let the too-comfortable and too-safe life die. ${ }^{[37]}$ Two modalities existing in parallels. Yet Frida Kahlo remains the most powerful reminder that what the French Surrealists Codified has always been an everyday reali: in Mexico and Latin America, part of the cultural stream, a spontaneous fusing of myth and fact, dream and vigil, reason and fantasy. ${ }^{[38]}$ Positive and negative space collide, as in a painting. Designers can tweak, colour, shade and adjust the illustrated aspects of playing cards to create variety, but a deck of cards ultimately is just a deck of cards, Right? ${ }^{[39]}$ Or in music the sound and the silence. Herb farm has always been organic, more out of pragmatism than green politics. ${ }^{[40]}$ With words can be recorded, the breathing of life, the thoughts that I record, the words that I hear with my ears. Buckwheat is no relation to wheat and is technically not even a grain (it is a grass seed, a member of the Dock and Rhubarb Family). ${ }^{[41]}$ The voice the

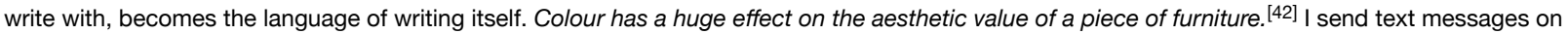
my smart phone. I keep many sketchbooks at any one given time and their all different types of paper and sizes. ${ }^{[43]}$ I send messages in cyber space. Without originality you are just another fish in the sea. ${ }^{[44]}$ Whilst I walk in the world. I think that running a business has made me a better designer. ${ }^{[45]}$ view the world from the eyes of an artist. Lizzie Marrkilyi Ellis has led an extraordinary life. ${ }^{[46]}$ I comment on the arts. who, what, wear. ${ }^{[4]]}$ I walk and think at the same time. I create whilst I think.

Dislocation in the arts has a long history. It is a history that converges with our contemporary informatic moment : a quantum, post-media moment when you can be here and there at the same time, a vectoral moment in which there is no longer any there, there, to begin with. In the age of the internet, location itself had become mobile decentred, fragmented. Communications networks have modified the way we relate to locality and presence. As Scott Mquire has noted, we are still struggling to come to terms with the strange valencies that telepresence brings with it, even as we spend more and more time in cyberspace. New media artists have also been exploring the perverse locations of dislocation for some years now and their work, like the work of new media theorists, actively engages with the emerging unconscious of the cyber age : and; yes it is indeed an unconscious structured like a language, this unsettling 'grammar for being elsewhere. ${ }^{[48]}$

To leave the work of the artist up to chance, to include the intervention of the space that is divided by sight. To include both worlds of the seen and unseen, in one whole, the invisible and the visible. To unite both forces. The Yin and the Yang. The in breath and the outbreath. The acts of speaking and hearing. These polar opposites combined are formed together to create a whole. This is where the picture seems complete, the artwork finishec The balance of harmony which resonates to the viewer rings superior. The point in time a sound resonates to a pitch of harmonics. This is the feelins of completeness of harmony and the intrinsic nature of god in the universe recreated in the artworks of the artist.

Lost In the information age.

\section{The Original Montage}


* Note to reader

This is the original 'Cagean' style montage, that turned into the 'lost in the information age essay.' This shows my working process of opening up boc on random pages and writing down the first sentence that appeared. (in chronological style on book shelf from right to left top to bottom)

\section{FABRIC OF THE HEAVENS}

On all counts the Greek astronomers were prepared to allow that the sphere of the fixed stars was very large. [49] 'Oh thou daughter dwelling in Egyp furnish thyself to go into captivity : for Noph shall be waste and desolate without an inhabitant. [50] We know the effects of the absence of gravity, a thing that was inconceivable not so long ago ; a man floating in space, alone, without wings or mechanism of any kind ! This we have all seen. [51]

The last vibration of the seventh eternity thrills through infinitude. ${ }^{[52]}$ Give your suggestions in the form of words that evoke images, either memories detailed plans or fantasy symbols. ${ }^{[53]}$ To get to Olivenca take one of the frequent Olivenca buses from the city bus station in Ilheus. ${ }^{[54]}$ Thus the entir episode is a gay carnivalesque travesty of the city's name. ${ }^{[55]}$ Into the Desert Navaho. 1904. ${ }^{[56]}$ Is there an elevator or Laundry Service? ${ }^{[57]}$ See dancing. ${ }^{[58]}$ At the end of the visit, we shook hands warmly. ${ }^{[59]}$ If I ever became friends with a dolphin I would never presume to teach such a creatul more evolved than most humans will ever be on the contrary, I would try to learn all the levels of insights and depths of wisdom a dolphin might be kind enough to share with me. ${ }^{[60]}$ Pineapple Fructose 2.1 Glucose 2.9[61] The skill of doing this movement without turning the game into a wrestling match is in positioning yourself perfectly to take your partner by surprise. [62] He makes his home in the characters and minds of gods and humans;

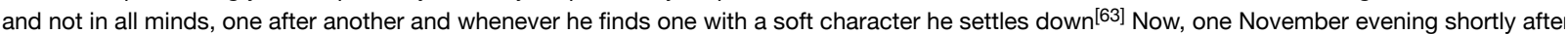
my mother's death, I was going through some photographs. ${ }^{[64]}$ Time is valuable and ten seconds worth of it is well worth the investment of a day's happy activity working out a way of saving it.[65] Werner Herzog was born in Munich on September 5, 1942. ${ }^{[66]}$ September 8 Walking for thousands Miles, Had you been In Capetown on September $8^{\text {th }}, 1928$, You would of seen a large crowd of people gathered together in the drizzling rain. ${ }^{67]}$ To send an email/fax. ${ }^{[68]}$ The watchman at the gate is the superconscious mind. ${ }^{[69]}$ Versals can be set: Outside the text, inside the text, half in and half outside the text, When outside, the text letters should be centred on a perpendicular line. ${ }^{[70]}$ In business, it was once the vogue to talk about 'winwin'situations. ${ }^{[71]}$ Thailand's border contains lush rainforest, weathered peaks, inviting fish-filled seas and those glorious islands and white sand beaches. ${ }^{[72]}$ Many of the censorship ordeals we run into are rooted in religious ideals and prudish notions. ${ }^{[73]}$ Transformation going on in an empty world which confronts us appear real all because of ignorance: try not to seek after the true, only cease to cherish opinions. ${ }^{[74]}$ Thus : Am I learning live more consciously? Am I learning greater self acceptance? Does my therapist's manner of dealing with me contribute to my experience of autonomy and empowerment? And so on. ${ }^{[75]}$ The train was passing through a forest. ${ }^{[76]}$ Roadblock. ${ }^{[77]}$ Probably not as often as we would like, we a have moments of extended bliss like this. ${ }^{[78]}$ This freed him from chronic financial worries and allowed him to devote the rest of his life to teaching a writing. ${ }^{[79]}$ We have seen that conflict is unavoidable. ${ }^{[80]}$ To go, depart, move. ${ }^{[81]}$ Petrol station. ${ }^{[82]}$ If a note is scribbled quickly, chances are the lette shapes in the words will be connected. [83] The wind chased me everywhere I went in Patagonia. ${ }^{[84]}$ Benso and Redpath use definitions for closed vs open forest and woodland vs open woodland set down by scientists in $1990 .{ }^{[85]}$ Researchers talk about how a creative person thinks and how a manic person thinks - the so called 'flight of ideas'. ${ }^{[86]}$ Wherever forests can develop in a species-appropriate manner, they offer particularly benefic functions that are legally placed above lumber production in many forest laws. [87] The supposed triumph of the 'Global Economy' seems to have turned out to be a rather hollow victory. ${ }^{[88]}$ The Spanish had butchered the Indians with a clean conscience because they were confident they knew what a normal human being was. ${ }^{[89]}$ Aries - Think the black granite bath is an ox-roasting pit. ${ }^{[90]}$ Elternhaus was created as a specific company to produce this perfume and its packaging. ${ }^{[91]}$ Shot on blurry webcams in the family basement or in jumbled, poster-covered bedroom, they variously resemble diaries, instruction manuals, music videos, and manifestos. ${ }^{[92]}$ Trigger points in these long extensors of the fingers project pain down the dorsum of the forearm to the back of the hand and often into the fingers dorsally. ${ }^{[93]}$ The hormone- influenced, 'right brain' (masculine) 'left brain' (feminine) theory that is the most popular concept of modern bio determinism is also under attack. ${ }^{\text {[94] }}$ Obesity and a degree of overweight that produce symptoms and secondary complications develop in about half of all adults. ${ }^{[95]}$ Beauty enlivens the commonplace. ${ }^{[96]}$ To a certain extent a man loses himself through connecting with his partner. ${ }^{[97]}$ It is typical for women to be afraid to let the too-comfortable and too-safe life die. ${ }^{[98]}$ Yet Frida Kahlo remains the most powerful reminder that what the French Surrealists Codified has always been an everyday reality in Mexico and Latin America, part of the cultural stream, a spontaneous fusing of myth and fact, dream and vigil, reason and fantasy. ${ }^{\text {[99] }}$ Designers can tweak, colour, shade and adjust the illustrated aspects of playing cards to create variety, but a deck of cards ultimately is just a deck of cards, Right? [100] Herb farr has always been organic, more out of pragmatism than green politics. [101] Buckwheat is no relation to wheat and is technically not even a grain (it is grass seed, a member of the Dock and Rhubarb Family). ${ }^{[102]}$ Colour has a huge effect on the aesthetic value of a piece of furniture. ${ }^{[103]}$ I keep many sketchbooks at any one given time and their all different types of paper and sizes ${ }^{[104]}$ Without originality you are just another fish in the sea. ${ }^{[105]}$ I thil that running a business has made me a better designer. ${ }^{[106]}$ Lizzie Marrkilyi Ellis has led an extraordinary life ${ }^{[107]}$ who, what, wear. ${ }^{[108]}$ Once you havı power, It's difficult to let go. ${ }^{[109]}$ 


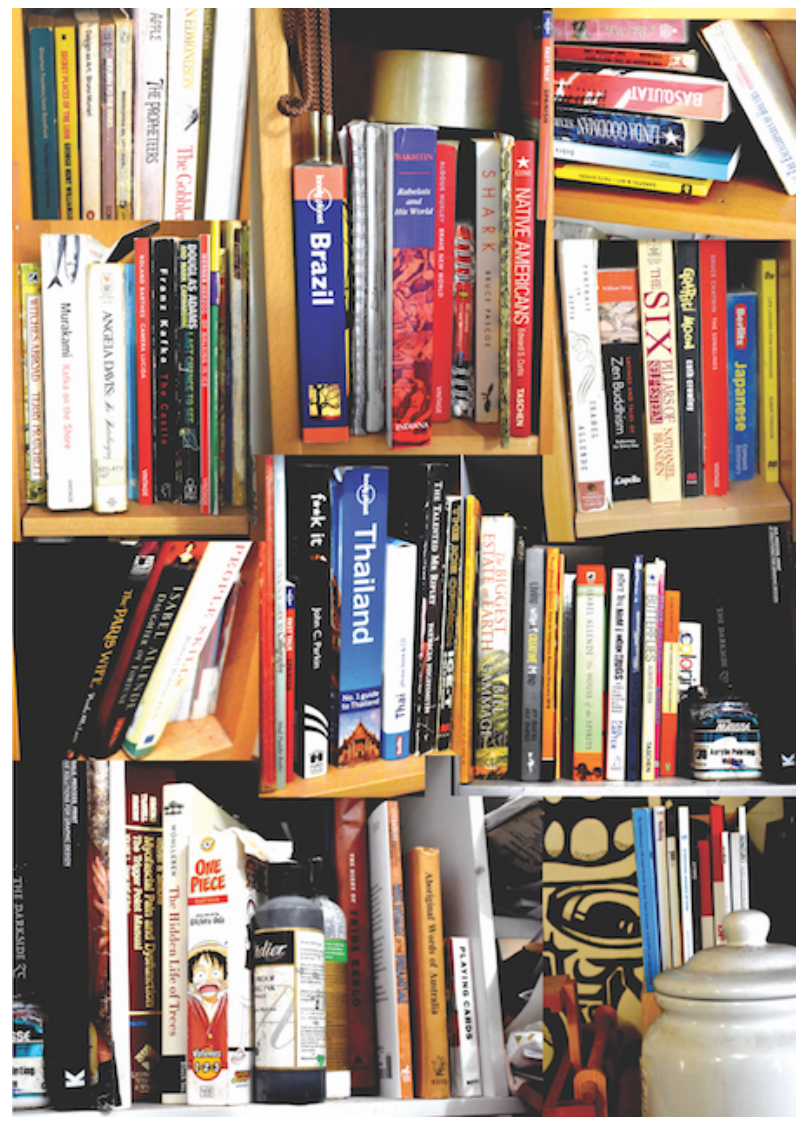

A Montage of the Author's Bookshelves

\section{Notes}

1. Hayles. N. 1994. "Chance Operations: Cagean Paradox and Contemporary Science.” In Perloff, Marjorie, and Charles Junkerman, eds. John Cage: Composed in America (Chicago: University of Chicago Press). pp. 227-40.

2. Moos, D. 1998. "Clairvoyant Memories the time of Sigmar Polke." In Art \& Text, vol 62. University of California. pp. 58-65.

3. Deleuze, G.\&F. Guattari. 1987. "Introduction: Rhizome." A Thousand Plateaus: Capitalism \& Schizophrenia. University of Minnesota Press.

4. Moos, D. 1998. "Clairvoyant Memories the time of Sigmar Polke," In Art \& Text, vol 62. University of California. pp. 58-65.

5. Foucault, M. 1970. "The Prose of the World." The Order of Things. Pantheon Books. Chapter 2.

6. Harris, D. 2001. "Quaintness." Cute, Quaint, Hungry And Romantic: The Aesthetics of Consumerism. Da Capo Press. pp. 23-50.

7. Dery, M. 2010. "Shovelware culture jamming hacking slashing and sniping in the empire of signs." Retrieved from http://markdery.com/? page_id=154.

8. Australian Bureau of Statistics. 2011-12. "Australian health survey physical activity." Retrieved from http://www.abs.gov.au/ausstats/abs@.nsf/lookup/4364.0.55.004Media\%20Release22011-12

9. Kellner, D. 2005. "Media culture and the triumph of the spectacle." Retrieved from https://pages.gseis.ucla.edu/faculty/kellner/papers/medculturespectacle.html.

10. Toulmin, S. \& J. Goodfield. 1961. The Fabric of the Heavens. Pelican Books, U.S.A

11. Williamson, G. H. 1958. The Secret of the Lion. Futura Books, Great Britain.

12. Munari, B. 1966. Design as Art. Penguin Books, Great Britain.

13. Daniken, E.V. 1970. Return to the Stars. Corgi Books, Great Britain. p. 151.

14. Kung, S.K. 2000. Instant Healing. St Martin's Press. p. 86.

15. Lonely Planet. 2002. Brazil. Lonely Planet Publications. p. 504.

16. Bakhtin, M. 1984. Rabelais and his World. Indiana Universtiy Press, USA. p. 192

17. Curtis, E.S. 2001. Native Americans. Taschen, Italy. p. 37.

18. Lonely Planet. 2009. Spanish, essential language for short trips. Lonely Planet Publications, Australia.

19. Guiley, R. 1995. The Encyclopedia of Dreams. Berkeley Books, New York. 
20. Hoban, P. 1998. Basquiat. Quartet Books, London. p. 226.

21. Goodman, L. 1988. Star Signs. Pan Books, London. p. 276.

22. Ledford, D \& B. 2009. Fructose Malabsorption: The Survival Guide. Ledford Publishers Brookings. p. 150.

23. Taylor, G. 2006. Capoeira 100. Blue Snake Books, Singapore. p. 200.

24. Plato. 1987. The Sypmposium. Penguin Books, England. p. 36.

25. Barthes, R. 1980. Camera Lucida. Vintage Books, London. p. 63.

26. Adams, D., and M. Carwardine. 1990. Last Chance to See. Pan Books, London. p. 36.

27. Herzog, W. 2014 Of Walking on Ice. Vintage, London.

28. Macmillan's Calendar Readers. 1949. September a story for everyday, Book 9. Richard Clay and Company, Great Britain. p. 29.

29. Lonely Planet. French an essential Language for Short Trips. Lonely Planet Publications, Australia. p. 60.

30. Harris, D. 2001. Quaintness Cute, Quaint, Hungry And Romantic: The Aesthetics of Consumerism. Da Capo Press. pp. 23-50.

31. Greenberg, C. 1985. "Avant-garde and kitsch." In Francis Frascina (ed.), Pollock and After: The Critical Debate. London: Harper \& Row. pp. 2 23.

32. Harris, D. 2001. Quaintness Cute, Quaint, Hungry And Romantic: The Aesthetics of Consumerism. Da Capo Press. pp. 23-50.

33. Gray, J. 1992. Men are from Mars, Women are From Venus. Griffin Press, Australia. p. 104.

34. 2015. Departures Magazine. Autumn Pacific Edition. p. 54.

35. 2015. Departures Magazine. Autumn Pacific Edition. p. 54.

36. Sudjic, D. 2009. The Language of Things. W.W Norton and Company, New York. pp. 13-46.

37. Estes, C. 1992. Women who run with the wolves. Rider, London. p. 80.

38. Lowe, S.M. 1995. The Diary of Frida Kahlo. Abrams, New York. p. 14.

39. Poole, B. 2005. Playing Cards. Mark Batty Publisher, New York. p. 86.

40. 2013. The Gentlewoman Magazine. Spring and Summer. p. 216.

41. Wellbeing Magazine. Issue 139. p. 58.

42. IDN Magazine. Issue 4. p. 19.

43. 2007. Juxtapose Magazine. March, Issue 74. p. 104.

44. 2008. Peak Street, Issue One, Jan 08. p. 76.

45. 2016. Art Collector Special Edition $201610^{\text {th }}$ Darwin Aboriginal Art Fair. p. 64.

46. Art Collector Special Edition $201610^{\text {th }}$ Darwin Aboriginal Art Fair. p. 64.

47. Frankie Magazine, 2010 issue 33, Jan/ Feb. p. 84.

48. Tofts, D. 2003. "Opaque melodies that would bug most people : a short history of dislocation in six tracks." Rhizomes 6. www.rhizomes.net/issues6/tofts.htm.

\section{MONTAGE}

49. Toulmin, S. \& J Goodfield. 1961. The Fabric of the Heavens. Pelican Books, U.S.A.

50. Williamson, G. H. 1958. The Secret of the Lion. Futura Books, Great Britain.

51. Munari, B. 1966. Design as Art. Penguin Books, Great Britain.

52. Daniken, E.V. 1970, Return to the Stars. Corgi Books, Great Britain. p. 151.

53. Kung, S.K. 2000. Instant Healing. St Martins Press. p. 86.

54. Lonely Planet. 2002. Brazil. Lonely Planet Publications. p. 504.

55. Bakhtin, M. 1984. Rabelais and His World. Indiana University Press, USA. p. 192.

56. Curtis, E.S. 2001. Native Americans. Taschen, Italy. p. 37.

57. Lonely Planet. 2009. Spanish, essential language for short trips. Lonely Planet Publications, Australia.

58. Guiley, R. 1995. The Encyclopedia of Dreams. Berkeley Books, New York.

59. Hoban, P. 1998. Basquiat. Quartet Books, London. p. 226.

60. Goodman, L. 1988. Star Signs. Pan Books, London. p. 276.

61. Ledford, D \&B. 2009. Fructose Malabsorption: The Survival Guide. Ledford Publishers, Brookings. p. 150.

62. Taylor, G. 2006. Capoeira 100. Blue Snake Books, Singapore. p. 200.

63. Plato. 1987. The Sypmposium. Penguin Books, England. p. 36.

64. Barthes, R. 1980. Camera Lucida. Vintage Books, London. p. 63.

65. Adams, D. and M. Carwardine. 1990. Last Chance to See. Pan Books, London. p. 36.

66. Herzog, W. Of Walking on Ice. 2014, Vintage, London.

67. Macmillan's Calendar Readers. 1949. September a story for everyday. Book 9, Richard Clay and Company, Great Britain. p. 29.

68. Lonely Planet. French an essential Language for Short Trips. Lonely Planet Publications, Australia. p. 60.

69. Shinn, F. C. 1940. The secret door to success. Devorss and Company, California.

70. Sasson, R. 2005. The Practical Guide to Calligraphy. Mud Puddle Books, New York. p. 45.

71. Parkin, J.C. 2015. Fuck It, The Ultimate Spiritual Way. Hay House, Sydney. p. 144.

72. Lonely Planet. Thailand. Lonely Planet Publications, Australia. p. 695.

73. Ice - T. 1994. The Ice Opinion. St Martins Press, New York. p. 124.

74. Wray, W. 2006. Zen Buddhism Reflections for Every Day. Arcturus Publishing, Singapore. p. 298.

75. Branden, N. 1994. Six Pillars of Self Esteem. Bantam Books, New York. p. 272.

76. Chatwin, B. 1987. The Songlines. Random House, London. p. 190. 
77. Berlitz. 2010. Japanese English Compact Dictionary. Berlitz Publishing, New York. p. 566.

78. Ferguson, R. 2013. Life Lessons from Kierkegaard. Macmillan, London. p. 31.

79. Hobart, M. and Z. Schiffman. 1998. Information Ages The Johns Hopkins University Press, Maryland. p. 190.

80. Bolton, R. 1979. People Skills. Touchstone Books, New York.

81. Tuttle. 2014. Thai dictionary. Tuttle Publishing, Singapore. p. 238.

82. Lonely Planet. 2012. Thai Phrasebook and dictionary. Lonely Planet Publications, Australia. p. 228.

83. Spiekerman, E. and E. Ginger. 2003. Stop Stealing Sheep and Find out how Type Works. Adobe.

84. National Geographic. 2004. "Mars: Is There Life in the Ancient Ice?" National Geographic Magazine. p. 55.

85. Gammage, B. The Biggest Estate On Earth. Allen And Unwin, NSW. p. 340.

86. Crabtree, J \& J. 2011. Living with a Creative Mind. Zebra Collective, NSW. p. 312.

87. Wohlleben, P. 2015. The Hidden Life of Trees. Black Inc., Australia. p. 244.

88. 2002. Globalisation, Origins, History Analysis, Resistance. 2002 Black Clad Hooligans Press, Globalisation series no. 1. Zine.

89. Botton, A.D. 2000. The Consolations of Philosophy. Penguin Books, Victoria. p. 140.

90. Hyde, S. 2016. The Darkside Of the Zodiac. Ivy Press, UK. p. 258.

91. Mason, D. 2007. Materials, Process, Print. Laurence King Publishing, UK. p. 107.

92. 2013. The New Yorker Magazine. March 18 Edn. p. 58.

93. Simons and Travell. 1999. Myofascial Pain and Dysfunction. Lippincott, Williams and Wilkins, New York. p. 713.

94. Steinem, G. 1992. Revolution from within Bloomsbury. Great Britain. p. 146.

95. Lean, M. Clinical Handbook of Weight Management. Martin Dunitz, London. p. 53.

96. Buscaglia. 1992. Born For Love. Fawcett Books, New York. p. 200.

97. Gray, J. 1992. Men are From Mars, Women are From Venus. Griffin Press, Australia. p. 104.

98. Estes, C. 1992. Women who Run with the Wolves. Rider, London. p. 80.

99. Lowe, S.M. 1995. The Diary of Frida Kahlo. Abrams, New York. p. 14.

100. Poole, B. 2005. Playing Cards. Mark Batty Publisher, New York. p. 86.

101. 2013. The Gentlewoman Magazine. Spring and Summer. p. 216.

102. Wellbeing Magazine. Issue 139. p. 58.

103. IDN Magazine. Issue 4. p. 19.

104. 2007. Juxtapose Magazine March, Issue 74. p. 104.

105. 2008. Peak Street Issue One, Jan 08. p. 76.

106. 2009. IDN extra 09 Red Thread. p. 89.

107. 2016. "Special Edition $10^{\text {th }}$ Darwin Aboriginal Art Fair." Art Collector. p. 64.

108. 2010. Frankie Magazine, Issue 33, Jan/Feb. p. 84.

109. 2015. Departures Magazine. Autumn, Pacific Edition. p. 54.

\section{Cite this Essay}

https://doi.org/10.20415/rhiz/034.e02

RHIZOMES ISSN 1555-9998 $\star 230$ East Hall Bowling Green State University Bowling Green, OH 43403

Editors: Ellen Berry and Carol Siegel. Reviews editor: Craig J. Saper. Technical editor: Helen J Burgess 